\title{
CONSUMER AND CORPORATE BEHAVIOR - BASIC DEPENDENCIES IN CONSUMERS' DAILY PATTERN BEHAVIOR
}

\author{
L. Spasova*, Zh. Gundasheva \\ Department of Social Sciences and Business Language Training, \\ Trakia University, Stara Zagora, Bulgaria
}

\begin{abstract}
The authors examine the impact of consumers' behavior on corporate behavior in terms of strategic thinking and planning. This is a very dynamic process where the development of specific strategies to influence consumers is almost impossible. The aim of this research report is to demonstrate through real examples of Bulgarian mobile operators the types of consumers and to find the objective and subjective reasons that influence the thinking and behavior of consumers. The following tasks were tackled in order to achieve this goal:

- Presentation of some mobile operators which impact different target groups.

- Survey of main strategies and techniques from business organizations which are targeting the different types of consumers.

The methods used for achieving this goal and resolving the tasks are: analysis of consumers and their behavior, analysis of successful practices, and comprehensive approach. The results indicate the need for analysis of dependencies and actual interests and decision-making process of consumers.
\end{abstract}

Key words: mobile operators, consumer types and interests.

\section{INTRODUCTION}

Studying customers' daily behavioral pattern, the resulting processes, and the implementation of leading corporate strategies for attracting and keeping customers engage representatives of various corporate communities in a continuous process of analysis and improvement of their policies and standards. Choosing a specific strategy to influence customers' behavior is not always readily effective. Many companies which offer services as mobile operators, insurance, airlines, etc. subdue their marketing policy to the overall purpose of the trade, such as selling high-tech and innovative products and services. However, this purpose is often unclear about the unconscious choices customers make and the rational and irrational motivation of the different types of consumers. Research in the field of business shows that the common features used to classify and differentiate the types of customers are closely related to the concept of "life cycle" of

\footnotetext{
*Correspondence to: Lyubomira Venkova Spasova, Department of Social Sciences and Business Language Training, Faculty of Economics, Trakia University, Stara Zagora, Bulgaria,e-mail: liubomira1975@abv.bg; GSM:088613829.
}

consumers' behavior and relationship with businesses (6).

The model of consumers' life cycle includes the following relationships: selection of appropriate target consumers, consumer activation, keeping the relationship with consumers, reactivation / winning back consumers, interruption of business relations. During the first two phases - selection phase and activation phase, commitment to the consumer is very weak, almost insignificant and therefore companies do not gain considerable profits because the investment in marketing activities, such as press releases, interviews, commercials, special events require extensive campaigning and resources, whereas consumers at this phase are not actively involved. In the phase of maintaining relationships with the consumer profits grow and the cost of sales decreases. This is the period when consumer satisfaction increases, and company management has to correct mistakes in client relationships. The creation of impulses for improving the delivery and models of long-term contracts with consumers for economic benefits can bring positive results for every company. 
The final phase, which includes the unfavorable relationship with the consumer, $i$. e. high costs in servicing many complaints or constant demands for price reductions could harm the company's image. There is a tendency for using negative messages which repel potential consumers, seriously harm the company image and significantly reduce its market share

\section{ANALYSIS OF CLIENT LOSS}

The reasons for client loss are multi-layered and are due not only to consumers themselves, but also to the one who offers products and services. Moreover, not all potential consumers from a target group become actual clients. Practice shows that the largest expenses in selling are made to entice potential clients, where the main tasks are to get to know consumers and stimulate their activity. For example, "Procter \& Gamble", which aims to promote their brands rather than the company as a whole, has a potential target group of, 5,000 users in the US. (3) Internationally this company faces difficulties in attracting new clients and this is explained by reasons such as its delayed entry to the Austrian market (1985), and the lack of corporate advertising in business publications. Therefore, the main task of company management in any business is to keep losses of any kind as low as possible.

A more precise definition of the types of consumers is represented by the following diagram:

\begin{tabular}{|l|}
\hline Potential target group - unattainable \\
\hline Actual target group - highly integrated, with impossible demands \\
\hline Stakeholders - hate risk, idealists \\
\hline $\begin{array}{l}\text { Probing, first-time buyers - freeloaders, dissatisfied with other } \\
\text { companies, clients in need for a change }\end{array}$ \\
\hline $\begin{array}{l}\text { Repeating buyers - dissatisfied, wishing a change, ready to risk, seeking } \\
\text { competitive offers }\end{array}$ \\
\hline Recommender - non-communicative \\
\hline
\end{tabular}

Figure 1. Analysis of client loss

Mobile operators in Bulgaria or in Europe and the US take different steps to prevent client loss by implementing various changes, such as the systematic product diversification and complementation, even when there are no competitive grounds for this. This practice is based under the assumption that if a consumer finds diversity in their traditional dealer it will be less likely that they would resort to the services of a competitor.

Regardless of the practical application of such strategies by the oldest Bulgarian mobile operator Mtel studies show a continuous loss of clients with an annual decrease of $4.9 \%$. In 2013 the company had over 5.5 million consumers, however, now client numbers have dropped with more than 200,000 - 5.3 million in all, with the company holding $44.8 \%$ of the market share. In 2013 the company's revenues fell by $16.3 \%$ to 300 million euros. In addition to the unfavorable macroeconomic situation the company was affected by the the regulator's reduction of wholesale prices, according to communications specialists (Telecom Austria).

Lower termination rates, the fees that operators charge to carry out mutual calls undermine business in Bulgaria, explains the parent company Telecom Austria. For or the period of 2005-2007, Mtel marked an increase of 23\% of consumer of fixed services on an annual basis, and mobile internet usage increased by nearly $17 \%$ on an annual basis. The third quarter was marked by a remarkable increase in sales of smartphones and tablets in telecom stores $52 \%$ for tablets and almost $100 \%$ for smartphones.

The results are not good for Telecom Austria AG for 2012-2013, one of the two major mobile trusts in Europe that Carlos Slim has a share in through his America Movil SAB. Profit before taxes for the third quarter fell to 357.9 million euros compared to 410.4 million euros. Sales revenue fell by 5.3 percent to 1.04 billion euros. Business in Austria, Bulgaria and Croatia is the biggest brake on profits reported the trust. In Croatia EBITDA crashed by 34 percent after roaming revenues decreased strongly after the country's accession to the European Union.

Industries with massive initial investment in attracting consumers have to examine the causes for consumer reorientation as research shows that after a phase of commitment, the 
risk of loss of confidence increases. Not only mobile operators are affected, but also insurance companies, legally regulated health insurance companies, vehicle manufacturers, workshops, publishers of newspapers and magazines, energy suppliers and others.
Therefore, companies from these sectors should be able to recognize the early onset of threats to be able to respond appropriately. Experienced managers have tried to identify the reasons for client loss by distinguishing objective from subjective reasons. (6)

\begin{tabular}{|l|l|}
\hline $\begin{array}{l}\text { Objective: } \\
\text { Expiration of the contract binding; } \\
\text { Better supply from competitors ; } \\
\begin{array}{l}\text { Errors in seller behavior ; } \\
\text { Defects. }\end{array}\end{array}$ & $\begin{array}{l}\text { General: } \\
\text { Personal changes (age, marital status, hobbies, } \\
\text { etc.). } \\
\text { Socio-demographic changes (income, profession, } \\
\text { etc.) } \\
\text { Economic factors (well-being, trends) }\end{array}$ \\
\hline $\begin{array}{l}\text { Subjective: } \\
\text { Dissatisfaction of consumers }\end{array}$ & $\begin{array}{l}\text { General: } \\
\text { The demand for change (Variety Seeking) }\end{array}$ \\
\hline
\end{tabular}

Figure 2. Reasons for client loss and termination of contact with companies

Socio-demographic changes affect the behavior of mobile operators' clients who gradually resort to other products and services that bring greater satisfaction. This trend is observed in cases when the same services are offered in a new area for consumers. As for services, such as insurances, the reasons for using them are the result of changes in age. This, in turn, can lead to termination of certain insurance contracts, which concern only family or single users. (9)

A key role in the termination of contracts of both private and corporate clients plays competition. On the basis of statistics we often find that the number of terminated contracts increases with the number of lucrative proposals by competitors. (6) Therefore, any new and advantageous offer from competitors can be an indicator for a change which is seen in banking products and mobile operators. These dependencies for Bulgaria should first be identified through relevant studies to become then the basis for taking specific measures. The aim is to identify the dependence between the characteristics of clients and the number of terminated contracts.

\section{SYSTEMATIZATION OF THE DEPENDENCIES FOR CONTRACT TERMINATION}

Whether the loss of consumers is too high or too low can be determined by direct comparison with other companies or after a period of time. This trend is evident in mobile operators in Bulgaria. As for the achievement of placement, they are found in a permanent reduction of the quota of losses. For controlling these measures a Preisner, A. (2003) created an indicator whose value is expressed in points. , If at each step we claim a
$50 \%$ share of losses, the $100 \%$ increase of attracted clients per a potential target group will lead to a $3 \%$ increase in the number of recommenders. It is therefore prudent to implement interesting pricing solutions.

If we look at the situation in Bulgaria, we will find that the launching of the third mobile operator in Bulgaria has created a real competition, compared to the situation when only two operators Mtel and Globul (now Telenor) keep the same rates and occupy the same market share. In the initial phase of mobile services in Bulgaria only one mobile operator was active for six years, i. e. the lack of competitive environment led to a lack of motivation on the part of Mtel to attract more consumers.

Another leading trend is the large participation of mobile operators in the field of advertising, which allows companies to reach different target groups. But for economic reasons it should not be attempted to attract the entire target group because it would lead to a steep rise in costs. Some losses here are perfectly reasonable. Exceptions are markets with a minimum number of consumers (6) (aircraft, in the automotive industry, municipalities) where individual non-consumers increase high potential losses.

Reasons for the loss of potential clients are mostly related to the lack of opportunities to identify consumers, and improper placement of products and services by the company. Other causes are inappropriate measures taken according to the marketing policy to advertise only indirectly to the target group and to vaguely inform the representatives about these decisions. Therefore, the company needs to think about how to improve communications. 
For example, with the entry of the third operator in Bulgaria - VIVACOM, a new competitive environment was created that signals new challenges for companies. Mobile operators were aware that they had to come up with new impressive messages in advertising and to be prepared for objective reasons that may deter the target group from being interested in a specific offer. This may be due to a long-term commitment to another provider, of non-compliance with certain requirements or insufficient purchase ability. If the operator is unable to comply with these facts, they must accept losses.

In the first years after BTC acquired a license for mobile operator, it was subjected to a strong pressure from the monopolist "Mtel", which together with the other operator "Globul" - now "Telenor"- were trying for a long time to resist the fall of connectivity costs between networks. This was happening under the pressure of the European Commission, which set deadlines for the reduction of prices.

After BTK- "VIVACOM" had been offering aggressively competitive prices for several years through big advertising campaigns, it managed to bind many subscribers with contracts for a combined service with mobile phones, landlines, internet and cable TV. Research shows that currently BTC, i. e. "VIVACOM" is the largest Internet provider. It is normal for a mobile operator to start its activity by attracting clients with more favorable offers and then to change the terms, in order to increase revenues. But in Europe in recent year's intense competition has led to price reduction of mobile phone calls and the European Commission as a regulator forced operators to cut prices within the EU.

If we analyze the stakeholders, i. e. the probing, first-time buyers, we will find that with the first purchase they overcome the biggest psychological barrier -risk of making a mistake. Furthermore, studies show that they are looking for more offers, finally choosing radically different options. The representatives of mobile operators are obliged to recognize these situations and act case-specific to support the buyer's decision.

Regular clients are particularly pleased with the supply and trust the seller. It is necessary to systematically apply measures to bind consumers. For example, 2012 is one of the most profitable years for mobile operator businesses in the country. All three telecoms reported growth in consumers, but registered decreases in revenue this year. This is explained by the saturation of the market of telecommunication services, and the reduction of incomes. Another explanation given by companies is the change in termination rates (connection) of national and international calls, which affects their revenues. Therefore rising prices, and reporting more income does not reflect positively on the overall development of the company.

\section{WIN OVER MANAGEMENT}

Losing customers is not new for a company with years of experience and the worst is that it can hardly be stopped. It's no secret that these consumers can be won again, that is why managers of mobile companies seek ways to achieve the ultimate goal - winning clients over.

Companies should conduct ongoing monitoring of the possible causes for hesitation in consumers. These reasons are varied, but in general they can be arranged in the following sequence: (5)

- Dropping a particular need;

- Customer dissatisfaction;

- More attractive proposition;

- Finding defects in products;

- Removal of products from the supply;

- Gaps in the product set.

When the consumer is subjected to frequent attacks, with no real intentions to leave, he feels annoyed and reacts only if he has been chosen for something. Intervention is needed only when the loss of clients is imminent. How will the company intervene depends on the potential contribution from the client as well as his possible intentions. (6)

\section{- $\quad$ The situation in Vivacom}

"Bulgarian Telecommunications Company" with trademark Vivacom is the third mobile operator and it reported an increase in profit for 2012 for up to 20.3 million. It's nearly a threefold increase compared to the 2011 data, according to the financial statements of the company. For 2011, the profit before taxing was just over 8 million. The large increase in profit is a result of optimizing its costs and better positioning of the portfolio of products and services in 2012. Report the telecom. The company notes a favorable trend of growth in the number of clients and a demand for their services. Revenues from mobile services Vivacom have increased by $7.8 \%$ on an annual basis to 397.8 million despite the reduced prices for termination. For the same period clients increased by $16.8 \%$, while mobile Internet users increased by $71.6 \%$ in 2012 compared to 2011. However, subscribers to TV services also increased by over $84 \%$. These results allow the company to compensate 
somewhat for the decline in revenues from fixed telephony. Total revenues for 2012 decreased with $3.4 \%$ to 857.9 million. The financial situation of the company remains stable with bank accounts and short-term bank deposits amounting to 63.9 million at the end of the year and paid dividends amounting to 158 million. It should be kept in mind that from the end of November last year BTC officially has a new owner. "NEF Telecom Bulgaria" sold its share of $93.99 \%$ in the company to the newly registered company "Viva Telecom Bulgaria" EAD. At the end of January this year, it became clear that the company "Viva Telecom Bulgaria" has made a proposal to buy the shares of the other shareholders of "Bulgarian Telecommunications Company."

\section{- The situation in Telenor}

Total revenues of "Cosmo Bulgaria Mobile" with the trade name "Globul" Telenor, now part of the Greek OTE Group, 2012 decreased by $8.5 \%$ to 738,5 million (377.6 million euros), while in 2011 amounted to 806.7 million (412.4 million euros). Earnings before interest, taxes, depreciation and amortization for the past year amounted to 264.8 million (135 million euros) with a decrease of $13.3 \%$ on an annual basis, was reported in a press release issued by the company. Only for the fourth quarter of 2012, total revenues decreased by $12.9 \%$ compared to the same period last year, the financial statements of the company. "Globul" think that the decrease in revenue is due to a sharp reduction in charges for termination imposed by the regulator, and because of changes in accounting policies of the company, introduced in September 2012 in order to harmonize practices in OTE Group. Service revenues for the quarter decreased by $20.9 \%$ mainly due to lower termination rates and changes in accounting policies of the company. Revenues of "Globul" before taxes, interest, depreciation and amortization for the fourth quarter of 2012 decreased in the last quarter of last year by $27.2 \%$ compared to the same period of 2011. At the same time consumers of the subscribing services increased, reaching 2.8 million by the end of 2012. This represents an increase of $8 \%$ compared to the same period of the previous year, or about $62 \%$ of the total consumer numbers. Despite the tendency for migration of consumers from prepaid to contract services, the number of users of prepaid services company also grew by $2.8 \%$ in the last quarter of the year, was reported by the company. In the end of 2012, the company's consumer numbers reach 4.5 million; while in the last quarter they increased by $5.9 \%$. And in the last three months of the year the tightening of consumer demand caused mainly by declining incomes, continued to influence the telecommunications market in Bulgaria, as strong competition in the sector continues to lead to falling retail prices, especially in the corporate sector, noted the company. At the end of 2012, the Bulgarian market was close to saturation point with penetration of mobile services of over $150 \%$, reported "Globul."

\section{- $\quad$ The situation in Mtel}

"Mobiltel" under the brand name of Mtel recorded a decrease in revenue of $11.1 \%$ to 917, 4 million (469.1 million euros) in 2012, and comparable earnings before interest, taxes, depreciation and amortization decreased by $20.8 \%$ to 405.6 (207.4 million euros). This shows the financial results for last year, announced by the Austrian company Telecom Austria Group, which is part of the Bulgarian telecom. The company said that in 2012 "Mobiltel" focused on high consumer segment and development of its multi-brand strategy. Last year the average consumer of Mtel paid $17.6 \%$ less for mobile services. At the same time the average revenue from fixed-line in 2012 decreased by nearly 22\%. Users of mobile services Mobiltel 5.6 million, as the company reported growth in consumers of $1.3 \%$ in 2012. The market share of the company for the past year was $46.9 \%$. The number of consumers of mobile internet has doubled compared to the previous year and amounted to 370.700 at the end of 2012. At the same time the company reported growth in the segment of fixed broadband. The number of consumers using fixed Internet increased by 23 $2 \%$ to over 150,000 subscribers, bringing the total number of fixed access lines to an increase of $21.5 \%$. The development of telecom business in Bulgaria in 2012 was marked by increased competition and lower termination rates, which seriously affected the performance of "Mobiltel" was noted by this telecom, as well. The change in prices for termination of national and international calls from July 1, 2012, led to a $50 \%$ reduction in revenues from this segment. Additionally, the Bulgarian market was marked by strong aggravated economic environment, was the comment of the telecom.

\section{CONCLUSION}

Client control offers a wide range of tools, which highlights the relationship between service providers, i. e. the company and the consumer. It can help to establish the economic success of individual user interfaces and the potential risk of permanent clientele. It should 
be remembered that an important starting point here is consumer value, $i$. e the consumer's potential to make a profit and create affiliations. In most cases this indicator is difficult to find and also there is no precise method for studying it. These are the main reasons that require gathering information from different sources. More developed companies take into account the customers' opinion and feedback to the company about its services.

Above all, we need to recognize the intention of consumers to leave, because then there is still the opportunity to take adequate action. Analysis of consumer behavior based on his information bank is possible only in long-term business relationships, and offers good opportunities for dependability in this direction. If the client cannot be dissuaded to leave, it should be considered whether it's worth it to be pursued and won over, keeping in mind that each case is individual and determined by the situation. Therefore, we've analyzed the dependency on the actual interest in the consumer, the likely reason for his decision and reaction.

\section{REFERENCES}

1. Belch E., Belch, A., Advertising and promotion-An integrated marketing communications perspective, $3^{\text {rd }}$ edn, The McGraw-Hill Companies, Boston, 1998.

2. Bettman, J., Memory factors in consumer choice: a review, Journal of marketing 43, vol. 29, no. 3, pp. 37-38, 2006.

3. Dowling, G., Create Corporate Reputations, ROI Communication Ltd., Boston, 2005.

4. Jagdish, N., Sheth, A., The role of motivation research in consumer psychology, University of Illinois, 2000.

5. Kotler, P., Lee, N., Corporate Social Responsibility, $1^{\text {st }}$ edn, ROI Communication Ltd., New York, 2011.

6. Preisner, A., Kundenmanagement leicht gemacht, $1^{\text {st }}$ edn, Eastra Holding Group, Munich, 2009.

7. Pring, R., Philosophy research, $2^{\text {nd }}$ edn, Book Continuum, London, 2004.

8. Robert, D., Buzzell, N., Can you standardize multinational marketing, Havard Business Review, London, p. 38, 1998.

9. Harris, T., Value-Added Public RelationsThe secret weapon of integrated marketing, ROI Communication Ltd., New York, 2002.

10.Phillips, D., Towards relationship management: PR at the core of organizational development, Journal of Communication Management, vol. 39, no. 6, pp. 20-21, 2000. 